\title{
Understanding Business Process Quality
}

\author{
Matthias Lohrmann and Manfred Reichert
}

\begin{abstract}
Organizations have taken benefit from quality management practices in manufacturing and logistics with respect to competitiveness as well as profitability. At the same time, an ever-growing share of the organizational value chain centers around transactional administrative processes addressed by business process management concepts, e.g. in finance and accounting. Integrating these fields is thus very promising from a management perspective. Obtaining a clear understanding of business process quality constitutes the most important prerequisite in this respect. However, related approaches have not yet provided an effective solution to this issue. In this chapter, we consider effectiveness requirements towards business process quality concepts from a management perspective, compare existing approaches from various fields, deduct a definition framework from organizational targets, and take initial steps towards practical adoption. These steps provide fundamental insights into business process quality, and contribute to obtain a clear grasp of what constitutes a good business process.
\end{abstract}

\section{Introduction}

Since the early 90 s, the concept of business process management (BPM) has achieved broad acceptance [3]. Consequently, business processes are increasingly subject to management methods such as planning, monitoring and controlling [36]. These methods generally presume insights into the aspired and actual business performance of the subject matter. For business processes, this means that managers strive to know what constitutes a good process and how to evaluate processes against this standard. Effective concepts to under-

Matthias Lohrmann · Manfred Reichert

Institute of Databases and Information Systems, University of Ulm, Germany,

e-mail: \{matthias.lohrmann, manfred.reichert\}@uni-ulm.de 
stand and methods to assess business process quality are thus a fundamental requirement to further establish BPM as a management practice. Considering the activities comprised in BPM lifecycle models (see, for instance, [3]), a sound understanding of business process quality can also provide business process design, implementation, enactment and subsequent analysis with an appropriate vision of success.

This chapter provides an overview on available approaches to business process quality and argues that these have not achieved full effectiveness yet. In particular, their views on business process quality are not sufficiently aligned to organizational needs and targets. We will show that, instead, present approaches mostly define business process quality implicitly by employing certain quality characteristics (e.g. related to business process input) without rigorously demonstrating the relation of these characteristics to organizational targets. We stipulate that this issue may be addressed by pursuing a deductive approach to derive a concept of business process quality from well-founded premises.

Accordingly, we propose a framework for business process quality as a foundation to guide the development of specific quality attributes, criteria and predicates, for instance with regard to particular application areas. As it rigorously systemizes organizational targets for business processes based on well-founded principles, it can also be used to design or evaluate BPM methodologies, for example in the area of process optimization.

Section 2 of this chapter presents our deductive design methodology including criteria to evaluate the effectiveness of results. In Section 3, we review existing approaches and match them against our effectiveness criteria. Based on basic terms shortly discussed in Section 4, Section 5 elaborates our concept of business process quality, which we apply to a practical example in Section 6. Section 7 concludes the chapter with a discussion of results and directions for future research.

\section{Deductive Design Methodology}

Business processes aim at achieving business objectives of the organization in an economic context $[9,19]$. Accordingly, we consider the concept of business process quality and associated methods like quality assessment or optimization as means to support this goal. This implies that business process quality is a goal-bound artificial construct as defined in the design science approach $[52,44,24]$. We therefore apply the respective research principles in the methodology set out in this section. 


\subsection{Effectiveness Criteria}

In design science, the value of design artifacts is to be judged "against criteria of value or utility" [44]. We subsume "value or utility" of an artifact as its effectiveness. Consequently, appropriate effectiveness criteria constitute an important part of our design methodology. We apply them in the evaluation of existing approaches as well as our results.

Business process quality artifacts are to be employed in the context of BPM activities as defined in [3]: design, enactment, control and analysis of operational processes. Out of these activities, analysis and control constitute the most relevant fields: the quality of business processes is assessed and analysed (either in the productive stage or even before), and control is exercised by feeding back into design and execution. We therefore derive our effectiveness criteria as comprised in Table 1 from requirements for effective managerial analysis and control [11].

\begin{tabular}{|c|c|c|}
\hline $\begin{array}{l}\text { Effectiveness crite- } \\
\text { ria }\end{array}$ & Rationale & Implications \\
\hline \multirow[t]{4}{*}{$\begin{array}{l}\text { EC 1: } \\
\text { Congruence to } \\
\text { organizational } \\
\text { targets }\end{array}$} & \multirow{2}{*}{$\begin{array}{l}\text { Explicit feedback loops in man- } \\
\text { agement control and perfor- } \\
\text { mance measurement systems } \\
\text { (e.g. [34]) }\end{array}$} & $\begin{array}{l}\text { Comprehensive coverage of } \\
\text { organizational targets for object } \\
\text { in question }\end{array}$ \\
\hline & & Exclusive coverage of organiza- \\
\hline & \multirow{2}{*}{$\begin{array}{l}\text { Content of performance mea- } \\
\text { sures impacts managerial be- } \\
\text { haviour and decisions }[20,48] \\
\text { ("What gets measured, gets } \\
\text { done!") }\end{array}$} & $\begin{array}{l}\text { tional target aspects for objects } \\
\text { in question }\end{array}$ \\
\hline & & $\begin{array}{l}\text { If full congruence cannot be } \\
\text { achieved: transparency on de- } \\
\text { ficiencies to mitigate defective } \\
\text { governance effects }\end{array}$ \\
\hline \multirow[t]{4}{*}{$\begin{array}{l}\text { EC 2: } \\
\text { Perceived fair- } \\
\text { ness }\end{array}$} & \multirow[t]{2}{*}{$\begin{array}{l}\text { Organizations as a social envi- } \\
\text { ronment: prerequisite for staff } \\
\text { motivation and change manage- } \\
\text { ment }\end{array}$} & $\begin{array}{l}\text { Governance: quality assessment } \\
\text { reflects organizational responsi- } \\
\text { bilities }\end{array}$ \\
\hline & & \multirow{3}{*}{$\begin{array}{l}\text { Transparency and retraceability: } \\
\text { accountable managers' under- } \\
\text { standing the link between status, } \\
\text { actions and assessment results, } \\
\text { limited complexity }\end{array}$} \\
\hline & $\begin{array}{l}\text { Performance measures are com- } \\
\text { monly used for individual target } \\
\text { setting and remuneration [57] }\end{array}$ & \\
\hline & $\begin{array}{l}\text { Equivalent provision for financial } \\
\text { reporting [27, paragraph } 46] \text { : } \\
\text { "true and fair view" }\end{array}$ & \\
\hline \multirow{3}{*}{$\begin{array}{l}\text { EC 3: } \\
\text { Cost effective- } \\
\text { ness }\end{array}$} & $\begin{array}{l}\text { Practical applicability in an } \\
\text { economic context }\end{array}$ & $\begin{array}{l}\text { Avoid large criteria catalogues } \\
\text { to be evaluated manually }\end{array}$ \\
\hline & \multirow[t]{2}{*}{$\begin{array}{l}\text { Equivalent provision for financial } \\
\text { reporting [27, paragraph } 44]\end{array}$} & $\begin{array}{l}\text { Avoid manual inspectment of } \\
\text { process instances }\end{array}$ \\
\hline & & $\begin{array}{l}\text { Formalize to allow for automated } \\
\text { assessment }\end{array}$ \\
\hline
\end{tabular}

Table 1 Effectiveness criteria 


\subsection{Course of Action}

As a preliminary step to detail our motivation for proposing an alternative approach towards business process quality, Section 3 substantiates our claim that available approaches are not fully effective from a management perspective. To this end, we conduct a literature review based on the effectiveness criteria set out in Table 1.

The remaining steps of our methodology are organized around the design processes of build and evaluate and the design artifact categories of constructs, models, methods and instantiations as set out in [44]. Figure 1 delimits design artifacts and processes with regard to business process quality.

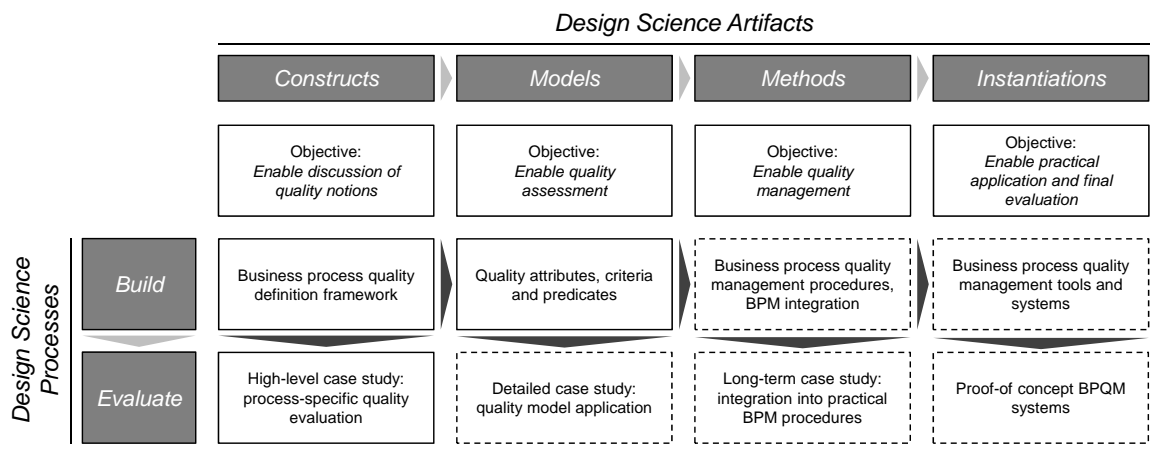

Fig. 1 Design methodology

In this chapter, we build our definition of business process quality, which represents a construct as it provides common ground to discuss this term. For practical application, it is a means to facilitate the definition of appropriate and measurable quality criteria. Corresponding sets of quality criteria which extend and further specify our definition, for example with respect to application areas such as finance or medicine, constitute models because they essentially relate business process quality to other constructs which can be assessed in practice. We also provide an outlook on possible model content while more formal and rigorous modeling will be subject to future work.

We evaluate our results with respect to our effectiveness criteria by way of application to a real-world business process. Methods and instantiations in the space of business process quality are topics for future work. 


\section{State of the Art}

Work related to the quality of business processes can be broadly divided into three categories: general management approaches that are also applicable to business process quality, BPM frameworks, and BPM research addressing individual aspects related to quality.

As stated above, we postulate that existing approaches towards business process quality are not yet fully effective from a management perspective. Therefore, this section first discusses related work and then presents a summary with respect to Effectiveness Criteria EC 1-3 from Table 1.

\subsection{General Management Approaches}

There are many management concepts which are not specific to the field of BPM but might be adapted for our area of research. We shortly discuss two selected approaches because of their wide practical adoption and their special relevance to business process quality.

Benchmarking is based on utilizing available experience and knowledge from comparable business processes: qualitative benchmarking matches the actual situation against known good practices, which may be documented in frameworks such as CobiT [31]. These practices may relate to organizational structures or directly to business processes or information systems. Quantitative benchmarking uses key performance indicators (KPIs) to measure process aspects. This enables comparison to results from peer organizations [5].

Example 1 (Good practices in process design and key performance indicators).

Consider the process of handling supplier invoices. Here, good practices for qualitative benchmarking include the use of early scanning (also known as "intelligent scanning", see our case example in Section 6) and Electronic Data Interchange (EDI) as ITbased practices, and credit note procedures as an organizational practice. The use of credit note procedures has been described in detail as an example for business process reengineering in $[10,18]$.

Quantitative key performance indicators include the number of invoices processed per full-time personnel resource and year, the processing cost per invoice, and average cycle time.

The balanced scorecard approach is used to measure and control organizational performance based on multiple dimensions: the "financial", the "customer", the "innovation and learning", and the "internal business" perspectives [33]. Key performance indicators are specifically developed for the organization and assigned to each dimension to allow for distinct tracking. Compared to traditional financial performance measures, the balanced scorecard recognizes that financials are always backwards-oriented and provide 
little clarity on an organization's future perspectives. Moreover, organizational goals are often contradictory, for instance when considering cash flow maximization against the need for investments. This issue has been long acknowledged in literature (e.g. [43]), and it is addressed via the multiple dimensions of the balanced scorecard; i.e., the approach does not try to combine everything into one single perspective. Of course, application of the original concept to business processes would require adaptation of even the fundamental scorecard perspectives, as they are defined to encompass all performance aspects of an organization instead of just business processes (which are considered as part of the "internal business" perspective). However, the basic idea of treating multiple performance dimensions as orthogonal instead of trying to find an absolute single measure of quality may be unavoidable for practical application.

\subsection{BPM Frameworks}

Research on BPM has also led to a wide array of proposals that might be applied to business process quality. A common characteristic of these approaches is that they, as opposed to benchmarking and the balanced scorecard, abstract from the business content of the processes in question. In other words, a person charged with executing the procedures proposed does not necessarily need to be a business subject matter expert.

An attempt to develop a "Quality of Business Processes (QoBP) framework" focusing on process models was made by Heravizadeh et al. [23]. Business process quality is defined in terms of 41 quality dimensions which are derived from literature, e.g. in the field of software engineering. The approach does not show the quality dimensions' interrelation to organizational targets or to an overall formal quality definition. This also means that we cannot determine whether the dimensions are complete or how to actually evaluate overall process quality. The quality dimensions are arrayed along the categories of function quality, input / output quality, non-human resource quality, and human resource quality. In our view, this is questionable because it mixes up the quality of a process under consideration with factors not under control of process management. In practical settings, this might lead to issues with the perceived fairness effectiveness criterion. The QoBP approach has been presented in more detail in [22]. In this context, quality has been defined as non-functional but distinguishing characteristics of a business process. We do not concur with that view because, from the perspective presented in Section 2, excluding the business objective of a process would neglect the goal-bound character of the business process quality construct as a design science artifact.

Heinrich and Paech proposed a business process quality framework based on software quality [21]. While work on software quality is not the only source 
used, the eight main "activity characteristics" with 27 sub-characteristics in [21] have been derived from this field. The "activity characteristics" are amended by four characteristics in the areas of "resource" and "actor". Similar to QoBP, this approach lists various quality characteristics, but it does not integrate them into a comprehensive formal quality definition, leading to similar issues as described above. Moreover, we stipulate that the applicability of software engineering results to design problems in the area of BPM still requires closer analysis.

Business process reengineering and optimization constitutes an area which is closely related to optimizing business process quality. [19, 9] provide good examples for the "classic" all-encompassing reengineering view. Reengineering approaches commonly comprise recommended best practices and other informal methods which are mostly based on anecdotal evidence. [54, 50, 39, 32] and, with a focus on well-defined process models, [4] constitute additional examples for optimization based on informal methods. This view is also reflected in the OMG Business Process Maturity Model [55] and other BPM maturity models [53] which suggest criteria to allocate business processes to maturity levels without giving clear evidence on how this structure is devised. While this informal character fits well with practical applicability, we still lack an overarching comprehensive model to ensure causal relations between measures recommended and intended results as well as completeness of coverage of quality aspects.

\section{3 ВPM Approaches Covering Individual Aspects}

In the field of BPM, a great number of approaches have been developed to address individual quality aspects of business processes. While they do not aim at an overarching construct of business process quality, they may still provide important methods for practical business process quality management.

There is some related work that deals with the quality of business process models: van der Aalst introduced soundness of Workflow Nets [1]. Hallerbach et al. discuss how to ensure soundness for an entire process family [17]. Finally, Reichert et al. enhance these considerations by also considering soundness in the context of dynamic process changes during run-time [49]. Weber et al. developed process model refactoring [60, 61]. Li et al addressed reference model discovery by model merging [37, 38]. Weber et al and Rinderle et al described quality issues in respect to a case-based capturing of knowledge about reusable process adaptations which can be applied in dynamic environments $[62,51]$. Ly et al. ensure that both the specification and the enactment of business processes are compliant to global rules and regulations [42]. Becker et al. discussed process model quality focusing on certain stakeholder groups and applications [4]. Gucegioglu and Demirors applied software quality characteristics to business processes [15]. Mendling 
assessed formal errors in EPC business process models [45] in an automated approach. Cardoso analyzed workflow complexity as one possible measure for process model quality [6], and Vanderfeesten et al. discussed quality metrics in business process modeling $[58,59]$.

There are also approaches to formally optimize business process or workflow models. Examples include $[2,1]$, where Petri nets are proposed to leverage existing analysis methods, and [25], where various optimization strategies for process designs with given input and output sets per activity are discussed. These approaches are mainly suited to optimize control flow and resource scheduling as they do not address individual activities in terms of necessity, effort or alternatives. They thus constitute important tools but cover only aspects of optimum business process design. We intend further analysis to be part of future work on quality in the process design lifecycle stage.

Process intelligence, process performance management and business activity monitoring are closely linked to the quality of process execution. Research in this area is very much driven by practical requirements and tends to take an operational, short-term view as opposed to our rather structural, long-term perspective of business process quality. Exemplary work includes [7, 26, 13] and reflects the close association of this field to industry and tool vendors. Also in the context of process enactment, Grigori et al. have developed a proposal to monitor and manage exceptions in process execution [14].

\subsection{Evaluation against Effectiveness Requirements}

Having reviewed existing approaches to business process quality, we can evaluate them against Effectiveness Criteria EC 1-3 as set out in Table 1. We summarize our conclusions in Table 2 .

Note that most approaches do not explicitly state a concise definition of business process quality. Instead, they employ either quality criteria or quality attributes. Statements on quality can be made based on an assessment whether quality criteria are fulfilled or not. Quality attributes are properties that may be used to evaluate quality when amended with target or threshold values (they then become quality criteria). Making this distinction may seem overdone at first. However, there are some crucial implications from being able to utilize a formal quality definition and quality criteria as opposed to quality attributes only:

- A short and concise business process quality definition as a construct facilitates to directly apply the corresponding quality view, for instance by matching against organizational targets on an abstract level. It reduces the risk of misinterpretations and makes the underlying quality notion accessible for straightforward discussion. This reflects the role of constructs as defined in [44]. 
- Business process quality attributes enable to discuss what is important to quality. It is possible to discuss each attribute's link to overall organizational targets, but difficult to judge whether a set of quality attributes completely represents the relevant organizational targets. Quality attributes alone are not sufficient to assess quality, but they may be amended to constitute quality criteria. "Productivity" or "the capability [...] to enable users to expend appropriate amounts of resources in relation to the effectiveness achieved" constitutes an example for a quality attribute taken from [23].

- Business process quality criteria enable us to distinguish between low and high quality for individual attributes by providing explicit or implicit threshold values. The latter may, for instance, be given by comparison to a peer group. They are therefore required to assess quality. Our "productivity" example for a quality attribute evolves into a quality criterion when "appropriate amounts of resources" are specified.

To clarify our conclusions, we summarize the respective business process quality definitions and the corresponding quality attributes or criteria in our overview on existing approaches. For approaches covering only individual aspects, evaluation against our primary Effectiveness Criterion EC 1 of congruence to organizational targets (cf. Table 1) as a whole is obviously not meaningful and therefore omitted.

Our review of present approaches resulted in some recurring issues that substantially affect effectiveness with respect to the criteria we chose to apply:

- There is an overall lack of a clear definition of business process quality in the sense of a construct. This makes it generally difficult to discuss and evaluate congruence to organizational targets, because completeness and adequacy of attributes or criteria lists remain debatable.

- Generally, BPM approaches tend to employ quality attributes instead of quality criteria. The classic reengineering and optimization approaches are the exception. In themselves, they are thus not sufficient to evaluate the concrete quality of a business process which impacts practical relevance.

- Assuming proper adaptation to the field of BPM, the balanced scorecard approach is the only one where we see high congruence to organizational targets: the approach was explicitly developed to accomodate the diverse and possibly conflicting target dimensions encountered in real-world business strategies.

- In all approaches discussed, perceived fairness is impacted by a failure to recognize the organizational environment of the business process by distinguishing between manageable and non-manageable factors. Nonmanageable factors in the organizational environment of a business process comprise, for instance, process input delivered by other ("upstream") business processes. This topic can often be observed in practice when benchmarking results are challenged by management if, for instance, very different organizations are chosen as peers. In this case, an impacted fairness 


\begin{tabular}{|c|c|c|c|c|c|}
\hline \multirow[t]{2}{*}{ Approach } & \multirow{2}{*}{$\begin{array}{l}\text { Business process } \\
\text { quality definition }\end{array}$} & \multirow{2}{*}{$\begin{array}{l}\text { Business process } \\
\text { quality attributes / } \\
\text { criteria }\end{array}$} & \multicolumn{3}{|l|}{ Effectiveness criteria } \\
\hline & & & $\begin{array}{l}\text { EC 1: Congruence to } \\
\text { organizational targets }\end{array}$ & $\begin{array}{l}\text { EC 2: Perceived fair- } \\
\text { ness }\end{array}$ & $\begin{array}{l}\text { EC 3: Cost effective- } \\
\text { ness }\end{array}$ \\
\hline \multicolumn{6}{|c|}{ General Management Approaches, see Section 3.1} \\
\hline $\begin{array}{l}\text { Qualitative } \\
\text { benchmarking }\end{array}$ & $\begin{array}{l}\text { Implicit: degree to } \\
\text { which good practices } \\
\text { are implemented }\end{array}$ & $\begin{array}{l}\text { Criteria: implementa- } \\
\text { tion of good practices } \\
\text { known from peer orga- } \\
\text { nizations }\end{array}$ & $\begin{array}{l}\text { Low: focus on copying } \\
\text { peer strategies with- } \\
\text { out consideration of } \\
\text { individual environment }\end{array}$ & $\begin{array}{l}\text { Low: failure to con- } \\
\text { sider organizational } \\
\text { constraints (e.g. capi- } \\
\text { tal expenditures) }\end{array}$ & $\begin{array}{l}\text { High: easy assessabil- } \\
\text { ity of good practices } \\
\text { implementation }\end{array}$ \\
\hline $\begin{array}{l}\text { Quantitative } \\
\text { benchmarking }\end{array}$ & $\begin{array}{l}\text { Implicit: degree to } \\
\text { which peer key perfor- } \\
\text { mance indicator values } \\
\text { are achieved }\end{array}$ & $\begin{array}{l}\text { Criteria: comparison to } \\
\text { key performance indi- } \\
\text { cator values achieved } \\
\text { at peer organizations }\end{array}$ & $\begin{array}{l}\text { Low: typically, focus } \\
\text { on efficiency measures } \\
\text { without consideration } \\
\text { of capital expenditures } \\
\text { or quality of process } \\
\text { input }\end{array}$ & $\begin{array}{l}\text { Low: efficiency mea- } \\
\text { sures typically do not } \\
\text { reflect non-manageable } \\
\text { factors (e.g. capital ex- } \\
\text { penditures or quality } \\
\text { of process input) }\end{array}$ & $\begin{array}{l}\text { High: key performance } \\
\text { indicators are typically } \\
\text { chosen for easy assess- } \\
\text { ability }\end{array}$ \\
\hline $\begin{array}{l}\text { Balanced scorecard } \\
\text { (with adaptations to } \\
\text { BPM application) }\end{array}$ & $\begin{array}{l}\text { Degree to which objec- } \\
\text { tives in target dimen- } \\
\text { sions (typically four) } \\
\text { are achieved }\end{array}$ & $\begin{array}{l}\text { Criteria: achievement } \\
\text { of objectives defined } \\
\text { for measures }\end{array}$ & $\begin{array}{l}\text { High: objectives and } \\
\text { measures are derived } \\
\text { from organizational } \\
\text { targets }\end{array}$ & $\begin{array}{l}\text { Dependent on defi- } \\
\text { nition of manageable } \\
\text { scorecard dimensions } \\
\text { (classic dimensions ap- } \\
\text { propriate for business } \\
\text { units) }\end{array}$ & $\begin{array}{l}\text { High: measures are } \\
\text { typically chosen for } \\
\text { high assessability }\end{array}$ \\
\hline \multicolumn{6}{|c|}{ BPM Frameworks, see Section 3.2} \\
\hline QoBP framework & $\begin{array}{l}\text { Implicit: degree to } \\
\text { which requirements } \\
\text { in quality dimensions } \\
\text { are fulfilled }\end{array}$ & $\begin{array}{l}\text { Attributes / criteria: } \\
\text { fulfilment of require- } \\
\text { ments in } 41 \text { quality } \\
\text { dimensions (require- } \\
\text { ments are not defined) }\end{array}$ & $\begin{array}{l}\text { Low: quality dimen- } \\
\text { sions are not system- } \\
\text { atically linked to orga- } \\
\text { nizational targets, no } \\
\text { consideration of target } \\
\text { interdependencies }\end{array}$ & $\begin{array}{l}\text { Low: quality require- } \\
\text { ments do not recognize } \\
\text { organizational environ- } \\
\text { ment }\end{array}$ & $\begin{array}{l}\text { Low: real-world mea- } \\
\text { surability of attributes } \\
\text { not proven, may lead } \\
\text { to protracted assess- } \\
\text { ment effort as mea- } \\
\text { sures are developed }\end{array}$ \\
\hline \multirow[t]{2}{*}{$\begin{array}{l}\text { Business process } \\
\text { quality framework } \\
\text { based on software } \\
\text { quality }\end{array}$} & $\begin{array}{l}\text { Implicit: degree to } \\
\text { which requirements } \\
\text { towards quality char- } \\
\text { acteristics are fulfilled }\end{array}$ & $\begin{array}{l}\text { Attributes: twelve } \\
\text { main quality charac- } \\
\text { teristics }\end{array}$ & see QoBP framework & see QoBP framework & see QoBP framework \\
\hline & & & & & Continued on next page \\
\hline
\end{tabular}




\begin{tabular}{|c|c|c|c|c|c|}
\hline \multirow[t]{2}{*}{ Approach } & \multirow{2}{*}{$\begin{array}{l}\text { Business process } \\
\text { quality definition }\end{array}$} & \multirow{2}{*}{$\begin{array}{l}\text { Business process } \\
\text { quality attributes / } \\
\text { criteria }\end{array}$} & \multicolumn{3}{|l|}{ Effectiveness criteria } \\
\hline & & & $\begin{array}{l}\text { EC 1: Congruence to } \\
\text { organizational targets }\end{array}$ & $\begin{array}{l}\text { EC 2: Perceived fair- } \\
\text { ness }\end{array}$ & $\begin{array}{l}\text { EC 3: Cost effective- } \\
\text { ness }\end{array}$ \\
\hline $\begin{array}{l}\text { Business process } \\
\text { reengineering and } \\
\text { optimization }\end{array}$ & $\begin{array}{l}\text { Implicit: all optimiza- } \\
\text { tion policies have been } \\
\text { leveraged }\end{array}$ & $\begin{array}{l}\text { Criteria: implemen- } \\
\text { tation of optimiza- } \\
\text { tion policies / matu- } \\
\text { rity level definitions } \\
\text { (similar to qualitative } \\
\text { benchmarking, but } \\
\text { independent of func- } \\
\text { tional content) }\end{array}$ & $\begin{array}{l}\text { Low: similar to quali- } \\
\text { tative benchmarking, } \\
\text { but peer strategies are } \\
\text { replaced with general } \\
\text { optimization policies }\end{array}$ & $\begin{array}{l}\text { Low: similar to quali- } \\
\text { tative benchmarking }\end{array}$ & $\begin{array}{l}\text { High: easy assessabil- } \\
\text { ity of implementation } \\
\text { of recommended prac- } \\
\text { tices }\end{array}$ \\
\hline \multicolumn{6}{|c|}{ BPM Approaches Covering Individual Aspects, see Section 3.3} \\
\hline $\begin{array}{l}\text { Quality of business } \\
\text { process models }\end{array}$ & $\begin{array}{l}\text { Implicit: optimization } \\
\text { levers for formal model } \\
\text { quality are fully uti- } \\
\text { lized }\end{array}$ & $\begin{array}{l}\text { Attributes: measures } \\
\text { for model quality (for- } \\
\text { mal definition but cov- } \\
\text { erage of individual as- } \\
\text { pects only) }\end{array}$ & $\mathrm{n} / \mathrm{a}$ & $\begin{array}{l}\text { Medium: formal mea- } \\
\text { sures allow for ob- } \\
\text { jective assessment, } \\
\text { but non-manageable } \\
\text { factors are not made } \\
\text { transparent }\end{array}$ & $\begin{array}{l}\text { Medium: assessment } \\
\text { automatable, but for- } \\
\text { mal modeling required } \\
\text { first }\end{array}$ \\
\hline $\begin{array}{l}\text { Business process } \\
\text { optimization: formal } \\
\text { approaches }\end{array}$ & $\begin{array}{l}\text { Implicit: formal con- } \\
\text { trol flow optimization } \\
\text { levers are fully utilized }\end{array}$ & $\begin{array}{l}\text { Attributes: measures } \\
\text { for process quality } \\
\text { with respect to con- } \\
\text { trol flow optimization }\end{array}$ & $\mathrm{n} / \mathrm{a}$ & $\begin{array}{l}\text { Low: aspects beyond } \\
\text { control flow (i.e., or- } \\
\text { dering of activities) } \\
\text { are not considered }\end{array}$ & $\begin{array}{l}\text { Medium: assessment } \\
\text { automatable, but for- } \\
\text { mal modeling required } \\
\text { first }\end{array}$ \\
\hline $\begin{array}{l}\text { Process } \\
\text { performance } \\
\text { management / } \\
\text { business activity } \\
\text { monitoring }\end{array}$ & $\begin{array}{l}\text { Implicit: target values } \\
\text { for process enactment } \\
\text { performance criteria } \\
\text { have been achieved }\end{array}$ & $\begin{array}{l}\text { Attributes / criteria: } \\
\text { process enactment per- } \\
\text { formance measures } \\
\text { without / with target } \\
\text { values }\end{array}$ & $\mathrm{n} / \mathrm{a}$ & $\begin{array}{l}\text { Low: non-manageable } \\
\text { factors important e.g. } \\
\text { for cycle times are } \\
\text { mostly not considered }\end{array}$ & $\begin{array}{l}\text { High: automated as- } \\
\text { sessment tools avail- } \\
\text { able to support work- } \\
\text { flow management sys- } \\
\text { tems }\end{array}$ \\
\hline
\end{tabular}

Table 2: Related approaches vs. effectiveness criteria 
perception due to a lack of consideration for the individual organizational environment leads to impaired acceptance of the entire assessment.

These conclusions provide some guidance to our further progress to design alternative artifacts:

- The current lack of concise definitions of business process quality encourages us to develop such a construct as a first build step as set out in our design methodology. The definition should be congruent to organizational targets as this is one of the major deficiencies of present approaches.

- To actually achieve congruence to organizational targets, we employ a deductive approach based on organizational targets for business processes. This methodology differs from existing approaches and will allow to verify congruence to targets at each stage of development.

- In our build model step, we place special regard to develop assessible quality criteria instead of mere quality attributes to achieve practical relevance in the analysis and control BPM lifecycle stages.

\section{Business Processes and Quality: Basic Concepts}

As a preliminary step to the development of our concept of business process quality, we have to ensure a common understanding on the basic concepts in the areas of business processes and quality we employ. This is particularly relevant because both terms have been the subject of a great number of attempts to find a definition over time (see, for instance, [40]). This section therefore shortly presents basic terms and definitions we adopt.

\subsection{Business Process Concepts}

The Workflow Management Coalition (WfMC) defines a business process as "a set of one or more linked procedures or activities which collectively realise a business objective or policy goal, normally within the context of an organisational structure defining functional roles and relationships" [64]. Summarizing this and other definitions, there is an overall agreement that a business process consists of a set of activities which aims at the realization of a business objective. This definition is very inclusive and covers virtually everything members of an organization undertake to serve organizational purposes. However, quality management in production and (direct) customer service is already well established (see the next section), and quality assessment makes the most sense when its results can be applied in future iterations. We therfore limit the context of our analysis to repetitive administrative processes. 
Moreover, we can distinguish between a business process model as an abstract notion and business process instances as concrete enactments thereof. The WfMC defines a process instance as "the representation of a single enactment of a process" [64]. For the more basic term business process, it remains open whether it refers to a process model or to a set of one or more process instances of one common process model [63]. In most applications, this distinction is made implicitly based on the business process lifecycle stage (cf. [3]). For our purposes, we discern between two fundamental lifecycle stages corresponding to the basic interpretations of the term business process.

Table 3 summarizes the fundamental lifecycle stages we use and compares to the business process management lifecycle in [3]. Note that our fundamental business process lifecycle for the purpose of quality management excludes the diagnosis stage as comprised in [3] because business process quality assessment is in itself part of this stage. Organizational capabilities in Lifecycle Stage I refer to the organization's ability to actually execute the process model in terms of available resources such as capital goods, personnel etc. The term actual process model designates a process model (which may be available as an organizational policy, as an explicit model in a modeling language or just as organizational knowledge) plus its actual implementation in terms of organizational capabilities such as the availability of information systems or machinery.

\begin{tabular}{lll}
\hline Fundamental lifecycle stage & $\begin{array}{l}\text { "Business pro- } \\
\text { cess"interpretation }\end{array}$ & $\begin{array}{l}\text { Corresponding lifecycle } \\
\text { stages in [3] }\end{array}$ \\
\hline $\begin{array}{l}\text { Lifecycle Stage I: } \\
\text { Business process design }\end{array}$ & $\begin{array}{l}\text { The business process as } \\
\text { an abstract process model } \\
\text { and its implementation } \\
\text { in terms of organizational } \\
\text { capabilities (actual process } \\
\text { model) }\end{array}$ & $\begin{array}{l}\text { Process design, system con- } \\
\text { figuration }\end{array}$ \\
& $\begin{array}{l}\text { The business process as a } \\
\text { set of one or more instances } \\
\text { of a common abstract pro- } \\
\text { cess model }\end{array}$ & Process enactment \\
$\begin{array}{l}\text { Businecycle Stage II: } \\
\text { ment }\end{array}$ & & \\
\end{tabular}

Table 3 Fundamental business process lifecycle stages

Contrary to most other BPM applications, business process quality assessment must address both fundamental lifecycle stages. From a management perspective, it makes sense to analyze both the quality of an actual process model and the quality of the corresponding process instances. Typically, organizational responsibilities differ for the fundamental lifecycle stages. To reflect this issue, separate results for both analyses are desirable (cf. Effectiveness Criterion EC 2 in Table 1). 


\subsection{Quality Concepts}

Since the 1950s, quality managment (QM) has become one of the central management concepts adopted by organisations globally. During that time, concepts and notions for quality have evolved from the work of pioneers such as Shewhart, Deming, Crosby, Feigenbaum, Juran and Ishikawa to standardized terminologies and methods that are propagated by trade and governmental bodies (for an overview see [8]). In terms of practical adoption, the definition of quality most widely spread today has been developed by the International Organization for Standardization (ISO) in the ISO 9000 series of standards [29]. As a set of norms in the area of QM for business applications, ISO 9000 has achieved broad acceptance through endorsements by governmental bodies like the European Union and the ISO 9000 certification scheme $[16,46,30]$. For a fundamental definition of quality, we therefore resort to the definition given in the ISO 9000 series of standards: quality denotes "the degree to which a set of inherent characteristics fulfils requirements".

The ISO definition, however, does not specify the concrete content of the "requirements". In this respect, various fundamental interpretations or views on quality have been argued. In [41], we gave an overview on these and discussed their fit in the context of BPM based on a classification developed by Garvin [12]. For our discussion, it is sufficient to record that the value-based view on quality, which matches the utility of an object against expenditures incurred, best suits our context, because it can accomodate the whole array of organizational targets. On the other hand, its implementation poses a number of challenges in practice which mostly relate to appraising the actual

"value" delivered as well as the actual expenditure incurred when considering issues such as the cost of upstream processes or risk management.

\section{A Framework for Business Process Quality}

As discussed in Section 4.2, quality in itself is an abstract term subject to differing interpretations. However, to be applied in a business context, it should be defined in a way to make it a useful construct for management purposes. Based on our design methodology (cf. Section 2) and the conclusions we made when reviewing existing approaches (cf. Section 3), this section derives a definition of business process quality which aims at achieving this goal.

Based on our analysis of related work, we proposed to deduct a definition of business process quality from organizational targets. Accordingly, our reasoning is built along four steps:

1. In terms of design science as described by Simon [52], a business process constitutes an artifact designed to attain goals by acting within its "outer environment". We stipulate that these goals correspond to the organiza- 
tional targets we refer to in Effectiveness Criterion EC 1 (cf. Table 1). Accordingly, we discuss the outer environment of the business process to focus and structure our field of analysis.

2. We identify and apply organizational targets for the outer environment of the business process. We then discuss how the business process affects the achievement of these targets during its fundamental lifecycle stages.

3. Based on the outer environment of the business process, the associated organizational targets and the respective impact of the business process in the course of its fundamental lifecycle, we state a definition framework for business process quality.

4. We refine the content of the definition framework to obtain a practically applicable model in the sense of the design science paradigm.

Steps 1 and 2 are addressed in Sections 5.1 and 5.2. Step 3 is presented in Section 5.3. We include initial considerations on Step 4 in Section 5.4.

\subsection{The Outer Environment of the Business Process}

When following the methodology set out above, congruence to organizational targets as our most pressing concern is mainly a matter of properly structuring the outer environment of the business process to be able to consider organizational targets comprehensively, but exclusively. Figure 2 summarizes various options.

\begin{tabular}{|c|c|c|c|c|c|c|c|}
\hline Design Science & \multicolumn{7}{|c|}{ Outer Environment } \\
\hline \multicolumn{2}{|l|}{$\begin{array}{l}\text { Common BPM } \\
\text { Perspective }\end{array}$} & Output & & Input & & Input & \\
\hline \multirow{2}{*}{$\begin{array}{l}\text { Scope of Influence } \\
\text { Perspective }\end{array}$} & \multicolumn{5}{|c|}{ Affected Environment } & & \\
\hline & & & \multicolumn{5}{|c|}{ Affecting Environment } \\
\hline $\begin{array}{l}\text { Organizational } \\
\text { Targets Perspective }\end{array}$ & Resources & \multicolumn{2}{|c|}{ Target Artifacts } & \multicolumn{4}{|c|}{ Resources } \\
\hline \multirow{2}{*}{ Disjoint Elements } & \multirow{2}{*}{ Externalities } & \multirow{2}{*}{$\begin{array}{c}\text { Target } \\
\text { Artifacts } \\
\text { Created }\end{array}$} & \multirow{2}{*}{$\begin{array}{c}\text { Target } \\
\text { Artifacts } \\
\text { Altered }\end{array}$} & \multicolumn{2}{|c|}{ Resources used and consumed... } & \multicolumn{2}{|c|}{ Resources used, but not consumed... } \\
\hline & & & & $\begin{array}{l}\ldots \text { attributable to } \\
\text { single instances }\end{array}$ & $\begin{array}{l}\text {...not attributable } \\
\text { to single instances }\end{array}$ & $\begin{array}{l}\ldots \text { attributable to } \\
\text { single instances }\end{array}$ & $\begin{array}{l}\text {...not attributable } \\
\text { to single instances }\end{array}$ \\
\hline
\end{tabular}

Fig. 2 Outer environment perspectives

An initial common BPM perspective on the outer environment is based on the concepts of process input and process output used by many authors (see, for instance, $[9,19])$. For our purposes, however, these concepts are not apt to properly structure the outer environment: First, input and output generally 
overlap if input objects are altered to assume a role as output object as well. This phenomenon is encountered in many business processes.

Second, interpretations of the term process input are prone to omit resources that are not attributable to individual process instances, such as capital goods (cf. [28]), or the availability of staff to execute activities. Usually, there is also no consideration of things affected unintentionally like exposure to litigation risks or pollution. In this case, the outer environment and, consequently, organizational targets are not considered comprehensively. Effectiveness Criterion EC 1 is thus impaired.

To obtain a more comprehensive view on the outer environment of a business process, we can assume a scope of influence perspective. The business process acts on part of its environment, and a part of its environment acts on the business process. We call these two parts the affected environment and the affecting environment of the business process. As an example, consider a document which is edited and thus affected in the course of the business process, and a piece of information which is affecting the business process because it is used to reach a decision. The two parts overlap, but things that belong to neither part are no component of the outer environment of the business process. For quality assessment, only the affected environment is of interest because things that are not affected by the business process are not relevant to judge its quality. ${ }^{1}$ However, it is still not possible to state organizational targets for the affected environment without further analysis, because it comprises the intended results of the business process as well as the consumption of economic resources.

We therefore propose an additional organizational targets perspective made up of two concepts: A business process interacts with its outer environment by manipulating (i.e., creating and/or altering) target artifacts and by using resources. The target artifacts involved in a business process are defined by the business objective. The resources involved are defined by the business objective as well as business process design, implementation and enactment. Target artifacts are the part of the outer environment we strive to alter while resources are the part we need to employ or unintentionally affect to achieve our business objective. Everything beyond these two categories is not relevant to the business process and therefore not part of its outer environment.

Note that target artifacts may evolve into resources in the context of another business process, and that resources drawn from are not necessarily consumed. We consider a resource as consumed if it is made unavailable to other uses, either permanently or only temporarily (e.g. a plot of land used is consumed temporarily). Resources not consumed are merely part of the affecting, but not of the affected environment. Resources consumed and target artifacts are part of the affected environment. Information generally constitutes a resource which is not consumed.

\footnotetext{
${ }^{1}$ Note that this proposition contradicts other quality frameworks for business processes which include, for instance, process input characteristics as quality attributes ([23, 21], cf. Section 3)
} 
Example 2 (Target artifacts and resources). To illustrate some of the concepts set out in this section, reconsider the process of handling supplier invoices we already used in Example 1. The business objective of this process is to approve or reject incoming invoices. They thus constitute the target artifacts of the process. Resources involved are affected by business process design, implementation and enactment.

According to Example 1, available design options comprise early scanning and EDI. These clearly differ in terms of resources such as information systems or labor required. Accordingly, the resources involved in the business process are determined by the chosen design option and its implementation. However, both options pursue the same business objective and work with the same target artifacts.

In the course of the process, the invoices are not created, but merely altered - in this case, an information item whether the invoice is approved or rejected is added. This information in turn constitutes a resource for the outgoing payments process which occurs downstream in the overall process chain.

The disjoint elements line in Figure 2 depicts a categorization of the outer environment where each thing in the outer environment belongs to exactly one category. It is thus comprehensive, free of overlaps and sufficiently expressive to build all other perspectives (for instance, Output $=$ Target Artifacts Created $\cup$ Target Artifacts Altered).

While the basic content categories as comprised in the disjoint elements line are universally valid, their concrete content in partially evolves over the lifecycle of the business process. With respect to the organizational targets perspective in Figure 2, the target artifacts part of the environment remains stable because the target artifacts of the business process are pre-determined by the business objective. ${ }^{2}$ The resources part, however, is subject to process design \& implementation. It therefore evolves with the business process lifecycle. This occurs in two ways:

- Resources used and affected condense and solidify in the course of the business process lifecycle. Before process design starts, only the general availability of resources to the organization and resources that are elemental to the business objective are determined. When process design \& implementation are completed, the types of resources used and affected are designated. Once the enactment of the business process has been completed, the environment of the business process is fully determined.

- The share of resources not only used, but consumed by a business process diminishes the more we advance in the business process lifecycle. Note that this closely resembles the concept of marginal cost accounting mostly used in German enterprises [35].

\footnotetext{
${ }^{2}$ We do not consider the decision on proper business objectives as part of the business process lifecycle. Contrary to that, the reengineering advocates of the 90 s proposed to rethink the business objectives of an organization as part of process design and optimization. While we do not share this view, we included a more detailed discussion on this topic in [41].
} 
In general, parts of the affected environment during business process design \& implementation become parts of the solely affecting environment during business process enactment. We will have to consider this issue in the course of our further investigation.

Example 3 (Resources in the business process lifecycle). Consider the business process to handle incoming supplier invoices which we already used in our previous examples. As we embark on the design of a corresponding business process, we may consider a number of options to achieve our business objective:

- We might manually send the invoices to the purchasing department and to the department which received goods or services for approval.

- We might implement one or more of the IT-based practices from Example 1.

At this stage, it is still open whether we employ organizational resources to implement an IT-based process or simply stick with more manual effort to distribute and recollect paper documents. However, if our business objective is to check invoices against purchase orders and goods receipts, purchase order information is an elemental resource and will be required regardless of process design. Likewise, if our organizational resources are not sufficient to implement IT solutions, we might have to consider this as a constraint as well.

Once the business process is implemented, however, we know what types of resources will be needed for enactment. The actual quantity per resource type will still depend on the actual number of process instances and their concrete enactment.

Regarding the diminishing share of resources that are actually consumed, consider the implementation of an EDI system. At deploy time, the system is in place regardless whether the business process is executed or not. The business process does not consume the EDI system as a resource. At design time, we get a different picture: whether and how the EDI system has to be implemented depends on the business process's design and will surely impact the consumption of resources.

Note that the business objective determines what is to be achieved by the business process in terms of target artifacts, but not how this should be accomplished. Moreover, per definition, direct materials (including information items) are the only kind of process input to be "embodied" into target artifacts. Accordingly, elemental resources determined by the business objective always relate to direct materials.

\subsection{The Impact of the Business Process on Organizational Targets}

The quality of a business process as an artifact needs to be assessed in terms of its impact on its outer environment. Based on our considerations on the environment of a business process (cf. Section 5.1), we can identify the set of organizational targets impacted by the business process and thus relevant 
to business process quality. We can readily determine "what the organization would want to achieve" with respect to both target artifacts and resources:

- With respect to target artifacts, the business objective of the process by definition constitutes one or more organizational targets. This aspect is typically addressed by conventional quality management approaches' focus on the quality of products and services delivered by business processes. It corresponds to the notion of efficacy as "the ability to produce a desired or intended result" [47].

- With respect to resources, we may assume that the organization aims to act economically (as may be inferred from the term business process). Accordingly, resources should be impacted as little as possible. This aspect is typically addressed by the focus of process performance management approaches on capacity management, cost and time. It corresponds to the common management notion of efficiency. Note that discussing organizational targets for the common BPM concept of process input would be much more difficult.

Assessing business process quality on the basis of relevant organizational targets amounts to appraising the impact of the business process on the achievement of the respective targets. To this end, we have to consider that a business process is enacted within an outer environment which comprises not only affected, but also affecting elements, i.e. resources used and target elements to be altered. Thus, the business process cannot "achieve" organizational targets, but merely contribute to their achievement. In other words, the affecting environment constrains the business process with respect to achieving organizational targets. To obtain a meaningful assessment of business process quality, we will need to delineate the impact of the affecting environment from the impact of the business process. Moreover, the affecting environment and the affected environment evolve with the business process lifecycle. Thus, the impact of the business process on organizational targets needs to be discussed specific to differing lifecycle stages as well.

To fulfil Effectiveness Criterion EC 2, we aim to recognize distinct organizational responsibilities for process design and process enactment as encountered in most organizations. Quality assessment results for business process design \& implementation should therefore not depend on the quality of business process enactment and vice versa. This implies that the business process design \& implementation lifecycle stage not only determines the types of resources employed and affected in business process enactment, but also that business process design \& implementation in itself is to be considered as part of the affecting environment during business process enactment. In a strict interpretation, this means that business process enactment will in itself actually not impact the achievement of organizational targets because the behaviour of the business process is fully determined by its design, its implementation, the resources used and the target artifacts to be altered. 
Example 4 (Impact of business processes vs. affecting environment). EDI systems for incoming invoices typically try to match invoices against purchase orders and goods receipts to determine whether the invoice can be posted and approved for payment. In this case, purchase order and goods receipt data constitute process input or resources employed. If one or both elements are missing, the ability of the business process to check the invoice in time will be impacted. As a result, it may not be possible to obtain an early payment discount or, worse, the supplier may decline to make new deliveries. In this case, the achievement of organizational targets is clearly impeded, but this is not the "fault" of our business process. Instead, elements of the affecting environment prevent achieving organizational targets. On the other hand, the EDI process alone cannot ensure timely payments because effective input of purchasing and goods receipt data is required as well. To effectively assess the quality of the EDI process, we have to properly delineate these effects.

As an example for differing requirements to delineate the affecting environment in the course of the business process lifecycle, consider that EDI operations are often outsourced to service providers subject to service level agreements. During design \& implementation, this is a deliberate decision under consideration of the quality of service required. Whether this decision is taken properly should enter quality assessment. During enactment, however, the availability of the EDI service becomes part of the affecting environment. When assessing enactment quality, we need to make sure that our results are not biased by EDI service failures.

Of course, this does not match practical requirements because assessing business process enactment quality is usually understood as assessing the quality of the human effort involved. Although human effort in principle constitutes a resource to the business process, we follow this interpretation for its practical relevance. However, we have to be aware that this decision implies a certain deviation from a fully stringent approach based on the business process as an artifact in the sense of Simon.

To summarize and exemplify the evolvement of the outer environment in terms of resources, Figure 3 illustrates the affecting and the affected environment for our fundamental lifecycle stages in terms of common business administration concepts.

Consider the following explanatory notes:

- As discussed in Section 5.1, target artifacts do not evolve with the business process lifecyle as they are pre-determined by the business objective. They are therefore not included in Figure 3.

- Capital goods refer to property, plant and equipment such as machinery, information systems, etc. In general, this corresponds to resources not attributable to individual process instances. Capital goods are an outcome of the business process design \& implementation lifecycle stage.

- Direct materials correspond to resources attributable to individual process instances. For our purpose, this includes information items (as well as special cases like dies, i.e. resouces used, but not consumed). Indirect materials correspond to supplies not attributable to individual process instances. 


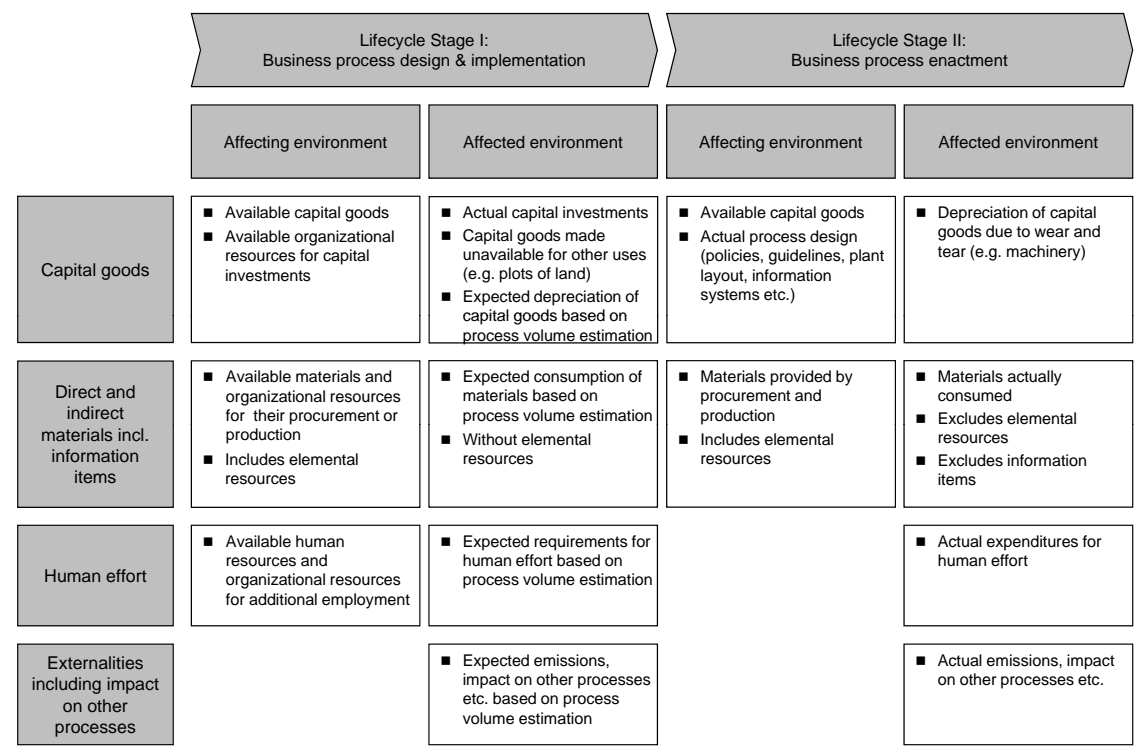

Fig. 3 Affecting and affected resources in the business process lifecycle

- Human effort refers to the quantity and quality of labor employed. Note that, as stated above, we do not include human effort in the affecting environment at the enactment stage.

- Externalities refer to unintended impacts caused including emissions and effects on other processes, e.g. when shared resources like machinery are made unavailable. Per definition, externalities are part of the affected environment, but not of the affecting environment.

- Note that the affecting environment for business process enactment also comprises the actual process design, i.e. the results of the process design \& implementation stage. This ensures that quality assessment of the enactment stage is not impacted by process design \& implementation. We included the actual process design with the capital goods category of resources because it comprises machinery and implemented information systems as well as intellectual property such as policies and guidelines. This inclusion also links both lifecycle stages in terms of their environments: the affected environment of process design \& implementation also comprises the affected environment of process enactment, and the affecting environment of process enactment comprises the affecting environment of process design \& implementation. The respective impact is "funneled" through the results of the design \& implementation stage. 


\subsection{Business Process Quality based on Organizational Targets}

In the previous sections, we made a number of conclusions to guide our definition of business process quality:

1. Business process quality has to be assessed in terms of the impact of the business process on its outer environment. For this purpose, its outer environment can be analyzed in two dimensions: the affecting vs. the affected environment, and target artifacts vs. resources.

2. There are differing organizational targets with respect to the target artifacts and resources parts of the affected environment. These targets correspond to business process efficacy and business process efficiency, respectively. As the affected environment will be determined by the business process and the affecting environment, the business process cannot achieve these organizational targets, but merely contribute to their achievement.

3. Affecting and affected resources evolve with the business process lifecycle. To reflect differing organizational responsibilities, business process quality must be assessable separately for business process design 83 implementation and for business process enactment.

Based on these considerations and on the ISO quality definition (cf. Section 4.2), we can derive a definition framework for business process quality:

\section{Definition 1 (Business process quality framework).}

Business process efficacy means the effectiveness of a business process with respect to achieving its business objective. A business process is efficacious iff its business objective is achieved for a reasonable set of states of its affecting environment.

Business process efficiency means the effectiveness of a business process with respect to limiting its impact on resources. A business process is efficient iff it limits its impact on resources reasonably considering the state of its affecting environment.

Business process design $\mathbb{E}$ implementation quality is the degree to which an actual business process model enables business process efficacy, achieves business process efficiency during design \& implementation, and enables business process efficiency during its enactment.

Business process enactment quality is the degree to which a set of business process instances achieves business process efficacy and business process efficiency.

According to the outer environment of the business process and the associated organizational targets, business process efficacy and efficiency constitute the two dimensions of business process quality requirements for both 
fundamental lifecycle stages. They both take into account the affecting environment, either by demanding achievement of the business objective only for "a reasonable set of states" of the affecting environment, or by considering the affecting environment in the evaluation of the impact on resources. A reasonable set of states in this context relates to what can be assumed regarding the affecting environment presuming effective upstream processes. This means that the business process, to be effective, must be able to function in common and expectable business circumstances. Similarly, reasonably limiting the impact on resources refers to avoiding waste and diligently managing resources. A more detailed analysis of these topics (for instance with regard to a special application area) is a core subject of business process quality modeling (see our methodology set out in Section 2).

Note that a business process can be efficacious, but not efficient, whereas efficiency is only possible if a measure of efficacy is achieved as well: if the business objective is not achieved, any resources consumed have not been used reasonably. Table 4 resolves the dimensions of business process quality in terms of efficacy and efficiency requirements and in relation to fundamental business process lifecycle stages and their respective affecting environment.

\begin{tabular}{llll}
\hline & & Quality requirements & \\
\cline { 2 - 4 } $\begin{array}{l}\text { Fundamental lifecycle } \\
\text { stage }\end{array}$ & $\begin{array}{l}\text { Affecting environ- } \\
\text { ment constraints }\end{array}$ & $\begin{array}{l}\text { Business process } \\
\text { efficacy }\end{array}$ & $\begin{array}{l}\text { Business process } \\
\text { efficiency }\end{array}$ \\
\hline $\begin{array}{l}\text { Lifecycle Stage I: } \\
\text { Business process } \\
\text { design \& imple- } \\
\text { mentation }\end{array}$ & $\begin{array}{l}\text { Available organiza- } \\
\text { tional resources }\end{array}$ & $\begin{array}{l}\text { Enable achievement } \\
\text { of the business objec- } \\
\text { tive with respect to } \\
\text { the target artifacts }\end{array}$ & $\begin{array}{l}\text { Limit the impact } \\
\text { on resources during } \\
\text { design \& implemen- } \\
\text { tation, and enable } \\
\text { to limit the impact } \\
\text { on resources during } \\
\text { enactment }\end{array}$ \\
$\begin{array}{l}\text { Lifecycle Stage II: } \\
\text { Business process } \\
\text { enactment }\end{array}$ & $\begin{array}{l}\text { Actual process de- } \\
\text { sign, target entities } \\
\text { to be altered, capital } \\
\text { goods, direct materi- } \\
\text { als }\end{array}$ & $\begin{array}{l}\text { Achieve the business } \\
\text { objective with respect } \\
\text { to the target artifacts }\end{array}$ & $\begin{array}{l}\text { Limit the impact on } \\
\text { resources }\end{array}$ \\
\hline
\end{tabular}

Table 4 Business process quality requirements

Our definition framework is rather plain and simple. This characteristic is required to enable straightforward discussion in a business context, for instance with respect to Garvin's five basic quality notions (cf. Section 4). It corresponds to the ISO definition of quality as "the degree to which a set of inherent characteristics fulfills requirements" [29]: "inherent characteristics" reflect the design and implementation of the business process during the respective lifecycle stage and the human effort involved during enactment, and the "requirements" are reflected by the quality stipulations we made with respect to business process efficacy and efficiency. 
However, due to the high level of abstraction we adopt, it remains difficult to concisely apply our definition to practical examples, so a more detailed model of business process quality extending Definition 1 is required. While we do not include a fully elaborated formal model of business process quality here, we provide an outlook on quality attributes, criteria and predicates to facilitate a better understanding.

\subsection{Outlook: Business Process Quality Modeling}

In this section, we provide an outlook on possible approaches to business process quality models. As described in Section 1, the main objective of business process quality models is to enable the assessment of business process quality. To this end, quality models basically consist of three components summarized in Figure 4.

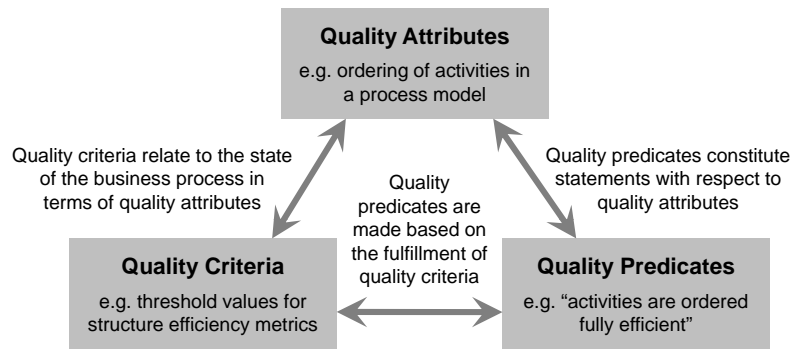

Fig. 4 Business process quality model components

Properties of business processes that are apt to determine or measure the impact of the business process on its environment with respect to organizational targets constitute the quality attributes of the business process. Quality attributes can assume states we can link to quality predicates, i.e. assertions on quality semantically suitable for the respective attribute. These states correspond to quality criteria. Accordingly, if a quality attribute assumes a state which fulfills a quality criterion, we may assign the respective quality predicate to the business process. Quality criteria reflect the requirements concept cited in the ISO quality definition.

According to our approach, it is generally desirable to rigorously derive quality attributes by applying Definition 1 and formal definitions of business processes, target artifacts, resources and their interrelation. However, we refer this approach to future work to avoid departing from the scope of this chapter. As an alternative to provide initial practical relevance, we provide an informal quality model along our definition framework. A good mental technique for this is to consider possible deficiencies that might occur. While this is similar 
to approaches based on listing possible quality attributes without rigorous derivation [23, 21], our extended discussion in Sections 5.1 to 5.3 still provides us with valuable insights and structure. We thus, for instance, avoid including process input properties as quality attributes to the business process.

Figure 5 summarizes the basic approach we apply to deduct an initial, non-formalized and simplified quality model: we first consider our lifecycle stages and the resulting artifacts, which are subject to quality assessment. Accordingly, assessing business process quality in Lifecycle Stage I amounts to assessing the quality of the actual process model, and assessing business process quality in Lifecycle Stage II amounts to assessing the quality of human effort during enactment. Both artifacts are then assessed with respect to their impact on the organizational targets of efficacy and efficiency. Additional guidance is provided by the overview on the resources part of the affected environment in Figure 3.

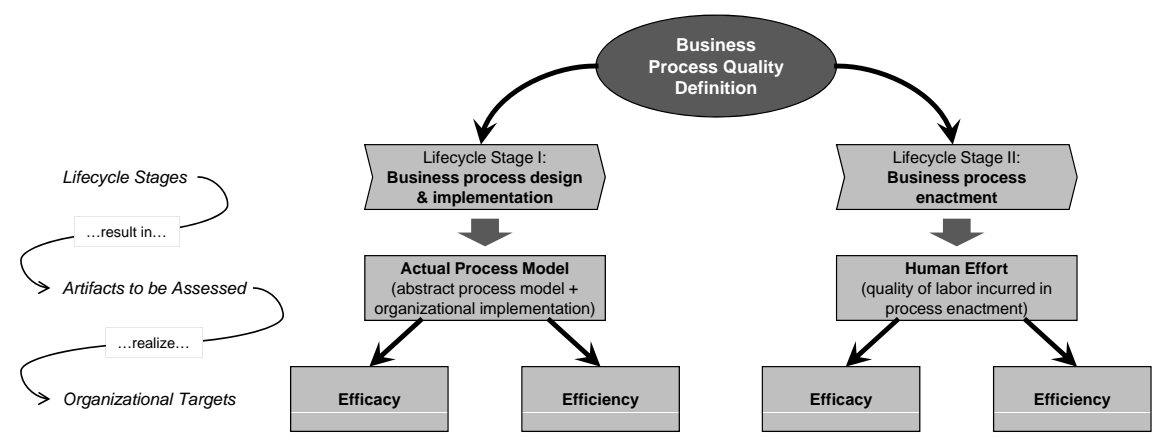

Fig. 5 Basic quality model deduction

Table 5 lists quality attributes, criteria and predicates we include in our simplified model. Because we do not formally deduct the entire quality model at this stage, we may not yet guarantee its completeness, and we may not give concisely measurable quality criteria. However, the structure along our discussion in the previous sections still allows for a measure of control in this respect, e.g. by considering the system of affected resources in Figure 3.

\begin{tabular}{llll}
\hline Ref. & Quality attributes & Quality criteria & $\begin{array}{l}\text { Quality } \\
\text { predicates }\end{array}$ \\
\cline { 5 - 5 } Business & process design E implementation & efficacy & \\
\hline A1 & $\begin{array}{l}\text { Formal or informal documenta- } \\
\text { tion of the business objective }\end{array}$ & $\begin{array}{l}\text { Business objective explicitly } \\
\text { modeled or documented as pre- } \\
\text { requisite to manage efficacy }\end{array}$ & $\begin{array}{l}\text { Transparent } \\
\text { and con- } \\
\text { trolled busi- } \\
\text { ness objec- } \\
\text { tive }\end{array}$
\end{tabular}

Continued on next page 
A2

Expectations and requirements regarding the actual affecting environment

A3

Relation between designated termination states and the business objective

A4 Consideration of procedures to manage deficiencies during business process enactment

A5 Relation between capital goods and business process model requirements

A6 Relation between staff capacity and business process model requirements
Expectations regarding the actual affecting environment have been reasonably derived and

documented / communicated

Control flow model conforms to the business objective (e.g. by formal derivation from the business objective)

Relevant cases covered acc. to affecting environment expectations, procedures comprised in actual process design

Capital goods available according to business process model as far as organizational resources have been available

Staff and procedures available according to business process model as far as organizational resources have been available

\section{predicates}

Managed affecting environment

Efficacious control flow design

Efficacious exception handling

Efficacious capital expenditures

Efficacious organizational implementation

Business process design $\mathcal{E}$ implementation efficiency

B1 Occurrence of non-value-adding activities and execution paths

Occurrence of resource waste in activities

$B 3$

Modeled sequence of activities: control flow designed to enable early break conditions towards termination states

B4 Design decisions: employment of capital goods vs. labor to implement automated vs. manual activities

B5 Skill requirements: employee skill levels required in manual activities
Control flow explicitly designed to avoid non-value-adding activities and execution paths

Activities are designed to avoid materials waste (e.g. clippings) and capacity waste (e.g. through idle time for staff or capital goods)

Avoidance of non-value-adding activities in possible execution paths regarding termination states, early execution of automated checks

Design decisions have been taken based on explicit business case considerations

Design decisions have been taken based on explicit business case considerations, activities and procedures are properly documented and trained
Controlled non-valueadding activities and execution paths

Controlled resource consumption in activities

Efficient break conditions

Controlled capital goods vs. labor trade-off

Controlled skill employment

Business process enactment efficacy

\begin{tabular}{llll}
\hline Occurrence of deviations from & $\begin{array}{l}\text { Prevalence reasonable with re- } \\
\text { the business process model in } \\
\text { manual decisions altering the } \\
\text { actual control flow path }\end{array}$ & business objective & $\begin{array}{l}\text { Efficacious } \\
\text { manual deci- } \\
\text { sions in the } \\
\text { control flow } \\
\text { path }\end{array}$
\end{tabular}




\begin{tabular}{|c|c|c|c|}
\hline Ref. & Quality attributes & Quality criteria & $\begin{array}{l}\text { Quality } \\
\text { predicates }\end{array}$ \\
\hline C2 & $\begin{array}{l}\text { Occurrence of deviations from } \\
\text { the business process model in } \\
\text { manual manipulations of target } \\
\text { artifacts or resources relevant to } \\
\text { the control flow in the course of } \\
\text { activity execution }\end{array}$ & $\begin{array}{l}\text { Prevalence reasonable with re- } \\
\text { spect to the criticality of the } \\
\text { business objective }\end{array}$ & $\begin{array}{l}\text { Efficacious } \\
\text { execution } \\
\text { of manual } \\
\text { activities }\end{array}$ \\
\hline C3 & $\begin{array}{l}\text { Occurrence of time delays in } \\
\text { manual execution of activities }\end{array}$ & $\begin{array}{l}\text { Prevalence and severity of time } \\
\text { delays reasonable with respect } \\
\text { to the criticality of the business } \\
\text { objective }\end{array}$ & $\begin{array}{l}\text { Timely ex- } \\
\text { ecution of } \\
\text { manual ac- } \\
\text { tivities }\end{array}$ \\
\hline$C_{4}$ & $\begin{array}{l}\text { Occurrence of manual alterations } \\
\text { to the actual process model (e.g. } \\
\text { overriding of IS customization) } \\
\text { in the course of the execution of } \\
\text { individual process instances }\end{array}$ & $\begin{array}{l}\text { Prevalence reasonable with re- } \\
\text { spect to the criticality of the } \\
\text { business objective }\end{array}$ & $\begin{array}{l}\text { Conformance } \\
\text { to the ac- } \\
\text { tual process } \\
\text { model }\end{array}$ \\
\hline \multicolumn{4}{|c|}{ Business process enactment efficiency } \\
\hline$D 1$ & $\begin{array}{l}\text { Occurrence of deviations from } \\
\text { the business process model } \\
\text { leading to redundant activities } \\
\text { caused by manual control flow } \\
\text { decisions }\end{array}$ & $\begin{array}{l}\text { Prevalence of redundant activ- } \\
\text { ities reasonable with respect } \\
\text { to complexity of control flow } \\
\text { decisions and additional effort } \\
\text { incurred }\end{array}$ & $\begin{array}{l}\text { Efficient } \\
\text { execution } \\
\text { regarding } \\
\text { redundant } \\
\text { activities }\end{array}$ \\
\hline D2 & $\begin{array}{l}\text { Occurrence of multiple execu- } \\
\text { tions of process instances or ac- } \\
\text { tivities due to activity execution } \\
\text { deficiencies }\end{array}$ & $\begin{array}{l}\text { Prevalence of multiple execu- } \\
\text { tions reasonable with respect to } \\
\text { complexity of respective tasks } \\
\text { and additional effort incurred }\end{array}$ & $\begin{array}{l}\text { Efficient } \\
\text { execution } \\
\text { regarding } \\
\text { multiple } \\
\text { executions }\end{array}$ \\
\hline D3 & $\begin{array}{l}\text { Occurrence of additional correc- } \\
\text { tive activities due to manually } \\
\text { caused deviations or deficiencies }\end{array}$ & $\begin{array}{l}\text { Prevalence of corrective activi- } \\
\text { ties reasonable with respect to } \\
\text { complexity of respective tasks } \\
\text { and additional effort incurred }\end{array}$ & $\begin{array}{l}\text { Efficient } \\
\text { execution } \\
\text { regarding } \\
\text { corrective } \\
\text { activities }\end{array}$ \\
\hline D4 & $\begin{array}{l}\text { Occurrence of manual re- } \\
\text { allocation of execution responsi- } \\
\text { bility for activities }\end{array}$ & $\begin{array}{l}\text { Prevalence of re-allocated activ- } \\
\text { ities reasonable with respect to } \\
\text { source (manual vs. automated) } \\
\text { and validity of original allocation } \\
\text { and additional effort incurred }\end{array}$ & $\begin{array}{l}\text { Efficient } \\
\text { execution } \\
\text { regarding } \\
\text { re-allocated } \\
\text { activities }\end{array}$ \\
\hline
\end{tabular}

Table 5: Simplified quality model

\section{Illustrative Case}

To illustrate our results, we apply our simplified quality model to a real-world business process in terms of its actual process model and an execution log.

In terms of content, our sample process corresponds to the examples given in the previous sections. Its business objective is to approve or disapprove incoming supplier invoices correctly and timely. In particular, it implements the early scanning design option already mentioned in Example 1. Our execution sample covers a total of 1,130 cases incurred over the period of one 
week, which have been tracked over the period of 15 weeks (cases not concluded within this timeframe are not considered). Figure 6 presents a BPMN flow chart of the business process model [56]. In addition, we base our evaluation on a central document describing the business process and its technical implementation (the so-called "blueprint").

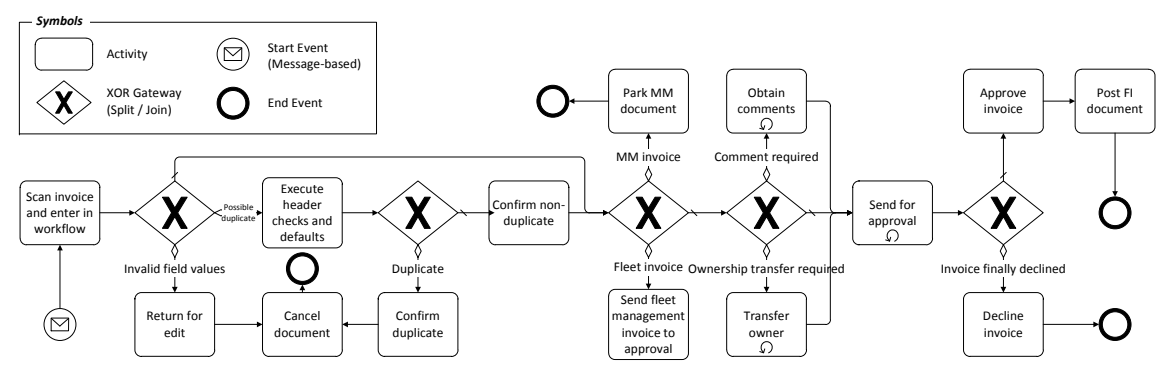

Fig. 6 Sample process: invoice handling

In Table 6, we apply the quality criteria set out in our simplified quality model in the previous section, and state the respective quality predicates.

\begin{tabular}{|c|c|c|}
\hline Ref. & Quality analysis & Quality predicates \\
\hline \multicolumn{3}{|c|}{ Business process design $E$ implementation efficacy } \\
\hline$A 1$ & $\begin{array}{l}\text { The business objective has not been formalized or docu- } \\
\text { mented in the blueprint, which governs process implemen- } \\
\text { tation and enactment }\end{array}$ & \\
\hline A2 & $\begin{array}{l}\text { The expected affecting environment has not been included } \\
\text { in the blueprint, but considered informally in actual pro- } \\
\text { cess design; an evaluation on the expected transactional } \\
\text { volume has been conducted }\end{array}$ & $\begin{array}{l}\text { Managed affecting } \\
\text { environment }\end{array}$ \\
\hline A3 & $\begin{array}{l}\text { While there is no formal documentation of the business } \\
\text { objective, use cases have been described in detail in the } \\
\text { blueprint. As use cases have been deducted from available } \\
\text { transactional data (cf. A2), we may therefore assume effica- } \\
\text { cious implementation }\end{array}$ & $\begin{array}{l}\text { Efficacious control } \\
\text { flow design }\end{array}$ \\
\hline A4 & $\begin{array}{l}\text { Exception handling routines have not been included in the } \\
\text { actual process design }\end{array}$ & \\
\hline$A 5$ & $\begin{array}{l}\text { Actual process execution as per the log sample implies } \\
\text { appropriate capital investments according to the process } \\
\text { design }\end{array}$ & $\begin{array}{l}\text { Efficacious capital } \\
\text { expenditures }\end{array}$ \\
\hline A6 & $\begin{array}{l}\text { Actual process execution as per the log sample implies } \\
\text { issues in organizational implementation (cf. C } 3, \mathrm{D} 2, \mathrm{D} 3 \text {, } \\
\text { D4) due to limited governance of process management over } \\
\text { process participants }\end{array}$ & \\
\hline \multicolumn{3}{|c|}{ Business process design $\mathscr{E}$ implementation efficiency } \\
\hline \multirow[t]{2}{*}{$B 1$} & $\begin{array}{l}\text { Non-value adding activities occur in the execution path } \\
\text { (manual re-allocation of responsibilities), "looping" of } \\
\text { check activities is possible }\end{array}$ & \\
\hline & & Continued on next \\
\hline
\end{tabular}




\begin{tabular}{|c|c|c|}
\hline Ref. & Quality analysis & Quality predicates \\
\hline B2 & $\begin{array}{l}\text { Capacity waste is avoided through the use of work item } \\
\text { lists for all user groups }\end{array}$ & $\begin{array}{l}\text { Controlled resource } \\
\text { consumption in activi- } \\
\text { ties }\end{array}$ \\
\hline B3 & $\begin{array}{l}\text { All automated checks are designed to occur at the begin- } \\
\text { ning of the control flow sequence }\end{array}$ & $\begin{array}{l}\text { Efficient break condi- } \\
\text { tions }\end{array}$ \\
\hline$B 4$ & $\begin{array}{l}\text { Design option decision (early scanning plus workflow) for } \\
\text { the business process is based on an explicit business case } \\
\text { consideration }\end{array}$ & $\begin{array}{l}\text { Controlled capital } \\
\text { goods vs. labor trade- } \\
\text { off }\end{array}$ \\
\hline B5 & $\begin{array}{l}\text { Actual skill employment is based on available resources in } \\
\text { the organization instead of documented requirements }\end{array}$ & \\
\hline \multicolumn{3}{|c|}{ Business process enactment efficacy } \\
\hline$C 1$ & $\begin{array}{l}\text { Deviations from the business process model do not occur } \\
\text { (execution fully controlled by the WfMS) }\end{array}$ & $\begin{array}{l}\text { Efficacious manual de- } \\
\text { cisions in the control } \\
\text { flow path }\end{array}$ \\
\hline C2 & $\begin{array}{l}\text { Correct handling of invoice approval is subject to both } \\
\text { internal and external audit procedures (risk-based audit } \\
\text { approach) }\end{array}$ & $\begin{array}{l}\text { Efficacious execution } \\
\text { of manual activities }\end{array}$ \\
\hline C3 & $\begin{array}{l}\text { Total processing time exceeds two weeks in } 10 \% \text { of cases, } \\
\text { mainly due to delays in the approval procedure }\end{array}$ & \\
\hline$C_{4}$ & $\begin{array}{l}\text { Manual alterations to the actual process model do not } \\
\text { occur }\end{array}$ & $\begin{array}{l}\text { Conformance to the } \\
\text { actual process model }\end{array}$ \\
\hline \multicolumn{3}{|c|}{ Business process enactment efficiency } \\
\hline$D 1$ & $\begin{array}{l}\text { Attribute not assessable: redundant activities may occur } \\
\text { where approval actions beyond the requirements based on } \\
\text { the invoice value are conducted. Due to data protection } \\
\text { concerns, we do not analyze this data }\end{array}$ & $\mathrm{n} / \mathrm{a}$ \\
\hline D2 & $\begin{array}{l}\text { "Return for edit" occurs in } 10 \% \text { of cases, leading to re- } \\
\text { peated manual check activities }\end{array}$ & \\
\hline D3 & $\begin{array}{l}\text { "Return for edit" occurs in } 10 \% \text { of cases, leading to correc- } \\
\text { tive activities in document capturing }\end{array}$ & \\
\hline D4 & Manual case ownership transfers occur in $34 \%$ of cases & \\
\hline
\end{tabular}

Table 6: Simplified quality model: sample application

In summary, the implications from our case example are twofold: First, we can summarize our assessment with respect to the quality of our sample business process. Second, we are now able to assess our initial design results with respect to the effectiveness criteria set out in Table 1.

With respect to our sample process, quality predicates made imply that the quality of the process largely reflects the chosen design option as a contemporary "best practice". Issues incurred mostly relate to topics where respective approaches have not yet reached practical acceptance (e.g. A1) or to governance issues during the enactment lifecycle phase. This may be due to the fact that, in this case, process management only partially controls process participants as invoice approval is "spread" throughout the organization.

When discussing this result with the responsible process manager, we found that our conclusions closely reflect her own appraisal of the situation. 
Regarding our effectiveness criteria, we arrive the following conclusions:

- Effectiveness Criterion EC 1: Congruence to organizational targets. Implications in respect to EC 1 are twofold. On the one hand, we can directly "drill down" from organizational targets to each quality attribute we consider. Accordingly, there are no issues with respect to exclusive coverage. On the other hand, we cannot ensure comprehensive coverage in our quality model. We stipulate that this restriction is caused by our deviation from a rigid deductive approach when drafting our simplified quality model.

- Effectiveness Criterion EC 2: Perceived fairness. Our quality model reflects basic organizational governance by adhering to fundamental business process lifecycle phases. However, as mentioned above with respect to the enactment lifecycle phase, a more fine-grained approach is required for our practical example. Moreover, our "binary" allocation of quality predicates is prone to omit important graduations. While our assessment results still point to issues to be addressed to improve on quality, organizational acceptance might still be impeded by these issues.

- Effectiveness Criterion EC 3: Cost effectiveness. Our illustrative case has shown that the simplified quality model can be applied with very small effort, provided that basic information such as, in this case, an implementation blueprint and an expressive execution log sample are available. This aspect, however, needs to be tracked as we move into more detailed quality models to further accommodate Effectiveness Criteria EC 1 and EC 2.

\section{Conclusion}

Business process quality management constitutes a highly promising area of research due to the application potential emphasized by the success of quality management practices in manufacturing and related fields. Moreover, a sound understanding of business process quality is a major prerequisite for effective BPM as is provides guidance to various activities along the BPM lifecycle.

In this chapter, we deducted three major effectiveness criteria from management requirements: congruence to organizational targets, perceived fairness, and cost effectiveness. We gave an overview on existing approaches, which we structured along general management approaches applicable to business process quality, BPM frameworks, and BPM approaches covering individual aspects.

Matching these approaches against the derived effectiveness criteria showed that an optimum solution for management purposes has not been achieved yet. More specific, a general lack of a concise definition of business process quality or related terms like business process performance, makes it difficult to discuss and evaluate the underlying notion of quality. Instead, BPM approaches in this area often confine themselves to adopting results from 
other areas without developing a meaningful definition first (cf. [13]). Thus, quality characteristics on a more detailed level tend to appear arbitrary, and their validity cannot be demonstrated. Moreover, many approaches provide attributes, but not criteria for quality, performance, etc. Thus, they are not sufficient to evaluate business process quality, which, in turn, impedes practical relevance. Finally, existing approaches mostly do not recognize differing organizational responsibilities for BPM activities and within a process chain. This also limits practical applicability.

To address these topics, we applied a rigorous methodology based on a notion of business processes as design artifacts in the sense of Simon [52] as well as appropriate effectiveness criteria. Accordingly, we analyzed the outer environment of business processes as a first step to obtain a definition of business process quality. We then discussed organizational targets with regard to components of the outer environment and the respective impact of business processes. We applied a business process lifecycle perspective to appropriately consider organizational structures.

These steps resulted in a concise definition of business process quality as a construct in line with the design science paradigm. The definition facilitates to derive appropriate quality attributes and criteria on a more detailed level.

As an initial proof of concept, we built a simple exemplary quality framework consisting of quality attributes and criteria structured according to our quality definition. We applied the sample framework to an illustrative real-world process example of 1,130 logged process instances. This led to promising initial insights that also reflect knowledgeable practitioners' appraisal of the sample case. Nevertheless, validation against the effectiveness criteria we defined still resulted in open issues and requirements. In line with our design methodology, these call for further research into a rigorous deductive approach to quality modeling. Major points comprise the need to rigorously deduct the quality model from accepted preliminaries to ensure comprehensive coverage, a more fine-grained approach to quality criteria, and the integration into BPM tools and methods to facilitate cost effective implementation.

In future work, we will therefore elaborate a more formal and detailed quality model which will also integrate available results from related aspects of BPM research, for instance with respect to formal optimization of business process models. Moreover, we intend to develop appropriate business process quality management procedures to enable integration into the general BPM lifecycle as well as common BPM tools. From a design science perspective, these will constitute method and instantiation artifacts. 


\section{References}

1. van der Aalst, W.M.P.: The application of Petri nets to workflow management. J. of Circuits, Systems and Computers 8(1), 21-26 (1998)

2. van der Aalst, W.M.P., van Hee, K.M.: Business process redesign: A Petri-net-based approach. Computers in Industry 29(1-2), 15-26 (1996)

3. van der Aalst, W.M.P., ter Hofstede, A.H.M., Weske, M.: Business process management: A survey. In: Proc. 1st Int'l Conf. on Business Process Management (BPM'03), LNCS, vol. 2678, pp. 1-12. Springer (2003)

4. Becker, J., Rosemann, M., von Uthmann, C.: Business Process Management, chap. Guidelines of Business Process Modeling, pp. 241-262. LNCS 1806. Springer (2000)

5. Camp, R.C.: Benchmarking: the search for industry best practices that lead to superior performance. Quality Press (1989)

6. Cardoso, J.: Business process quality metrics: Log-based complexity of workflow patterns. In: Proc. 15th Int'l Conf. on Cooperative Information Systems (CoopIS'07), $L N C S$, vol. 4803, pp. 427-434. Springer (2007)

7. Castellanos, M., Casati, F., Dayal, U., Shan, M.: A comprehensive and automated approach to intelligent business processes execution analysis. Distributed and Parallel Databases 16(3), 239-273 (2004)

8. Dale, B.G.: Managing Quality, 5th edn., chap. The Received Wisdom on TQM, pp. 58-73. Wiley-Blackwell (2007)

9. Davenport, T.J.: Process Innovation: Reengineering Work through Information Technology. Harvard Business School Press (1993)

10. Davenport, T.J., Short, J.E.: The new industrial engineering: Information technology and business process redesign. Sloan Mgmt. Review 31(4), 11-27 (1990)

11. Epstein, M.K., Henderson, J.C.: Data envelopment analysis for managerial control and diagnosis. Decision Sciences 20(1), 90-119 (1989)

12. Garvin, D.A.: What does "product quality" really mean? Sloan Mgmt. Review 26(1), 25-43 (1984)

13. Glykas, M.M.: Effort based performance measurement in business process management. Knowledge and Process Mgmt. 18(1), 10-33 (2011)

14. Grigori, D., Casati, F., Dayal, U., Shan, M.: Improving business process quality through exception understanding, prediction, and prevention. In: Proc. 27th Int'l Conf. on Very Large Data Bases (VLDB'01), pp. 159-168. Morgan Kaufmann (2001)

15. Guceglioglu, A.S., Demirors, O.: Using software quality characteristics to measure business process quality. In: Proc. 3rd Int'l Conf. on Business Process Management (BPM'05), LNCS, vol. 3649, pp. 374-379. Springer (2005)

16. Guler, I., Guillén, M.F., Macpherson, J.M.: Global competition, institutions, and the diffusion of organizational practices: The international spread of ISO 9000 quality certificates. Administrative Science Quarterly 47(2), 207-232 (2002)

17. Hallerbach, A., Bauer, T., Reichert, M.: Guaranteeing soundness of configurable process variants in Provop. In: Proc. 11th IEEE Conference on Commerce and Enterprise Computing (CEC'09). IEEE Computer Society Press (2009)

18. Hammer, M.: Reengineering work: don't automate, obliterate. Harvard Business Review 68(4), 104-112 (1990)

19. Hammer, M., Champy, J.: Reengineering the Corporation. A Manifesto for Business Revolution. HarperBusiness (1993)

20. Healy, P.M.: The effect of bonus schemes on accounting decisions. J. of Accounting and Economics 7(1-3), 85-107 (1985)

21. Heinrich, R., Paech, B.: Defining the quality of business processes. In: Proc. Modellierung 2010, LNI, vol. P-161, pp. 133-148. Bonner Köllen (2010)

22. Heravizadeh, M.: Quality-aware business process management. Ph.D. thesis, Queensland University of Technology, Australia (2009) 
23. Heravizadeh, M., Mendling, J., Rosemann, M.: Dimensions of business processes quality (QoBP). In: Proc. Business Process Management Workshops (BPM'08), $L N B I P$, vol. 17, pp. 80-91. Springer (2009)

24. Hevner, A.R., March, S.T., Park, J., Ram, S.: Design science in information systems research. MIS Quarterly 28(1), 75-105 (2004)

25. Hofacker, I., Vetschera, R.: Algorithmical approaches to business process design. Computers and Operations Research 28(13), 1253-1275 (2001)

26. IDS Scheer: Process intelligence white paper: What is process intelligence? (2009). http://www.process-intelligence.com

27. International Accounting Standards Board: Framework for the Preparation and Presentation of Financial Statements (1989). http://eifrs.iasb.org

28. International Accounting Standards Board: International Accounting Standard 16: Property, Plant and Equipment (2003). http://eifrs.iasb.org

29. International Organization for Standardization: ISO 9000:2005: Quality management systems - Fundamentals and vocabulary (2005)

30. International Organization for Standardization: The ISO Survey - 2007 (2008). URL http://www.iso.org. http://www.iso.org/

31. IT Governance Institute: CobiT 4.1 (2007). http://www.isaca.org

32. Jansen-Vullers, M.H., Kleingeld, P.A.M., Loosschilder, M.W.N.C., Netjes, M., Reijers, H.A.: Trade-offs in the performance of workflows - quantifying the impact of best practices. In: Proc. Business Process Management Workshops (BPM'07), LNCS, vol. 4928, pp. 108-119. Springer (2007)

33. Kaplan, R.S., Norton, D.P.: The balanced scorecard: Measures that drive performance. Harvard Business Review 70(1), 71-79 (1992)

34. Kennerley, M., Neely, A.D.: Business performance measurement: theory and practice, chap. Performance measurement frameworks: a review, pp. 145-155. Cambridge University Press (2002)

35. Kilger, W., Pampel, J.R., Vikas, K.: Flexible Plankostenrechnung und Deckungsbeitragsrechnung, 12th edn. Gabler Verlag (2007). In German

36. Koontz, H., O'Donnell, C., Weihrich, H.: Essentials of Management, 3rd edn. Tata McGraw-Hill (1982)

37. Li, C., Reichert, M., Wombacher, A.: Discovering reference process models by mining process variants using a heuristic approach. In: Proc. 7th Int'l Conf. on Business Process Management (BPM'09), LNCS, vol. 5701, pp. 344-362. Springer (2009)

38. Li, C., Reichert, M., Wombacher, A.: The MinAdept clustering approach for discovering reference process models out of process variants. Int'l J. of Cooperative Information Systems 19(3-4), 159-203 (2010)

39. Liman Mansar, S., Reijers, H.A.: Best practices in business process redesign: use and impact. Business Process Mgmt. J. 13(2), 193-213 (2007)

40. Lindsay, A., Downs, D., Lunn, K.: Business processes - attempts to find a definition. Information and Software Technology 45(15), 1015-1019 (2003)

41. Lohrmann, M., Reichert, M.: Basic considerations on business process quality. Tech. Rep. UIB-2010-03, University of Ulm, Germany (2010)

42. Ly, L.T., Knuplesch, D., Rinderle-Ma, S., Goeser, K., Pfeifer, H., Reichert, M., Dadam, P.: SeaFlows toolset - compliance verication made easy for process-aware information systems. In: Proc. CAiSE Forum 2010 - Information Systems Evolution, $L N B I P$, vol. 72 , pp. 79-91. Springer (2010)

43. March, J.G.: Bounded rationality, ambiguity, and the engineering of choice. Bell J. of Economics 9(2), 587-608 (1978)

44. March, S.T., Smith, G.F.: Design and natural science research on information technology. Decision Support Systems 15(4), 251-266 (1995)

45. Mendling, J.: Detection and prediction of errors in EPC business process models. Ph.D. thesis, WU Wien, Austria (2007) 
46. Neumayer, J., Perkins, R.: Uneven geographies of organizational practice: explaining the cross-national transfer and diffusion of ISO 9000. Economic Geography 81(3), 237-259 (2005)

47. Oxford University Press: Oxford Dictionaries Online, Keyword: Efficacy. http://oxforddictionaries.com

48. Prendergast, C.: The provision of incentives in firms. J. of Economic Literature 37(1), 7-63 (1999)

49. Reichert, M., Rinderle-Ma, S., Dadam, P.: Flexibility in process-aware information systems. LNCS Transactions on Petri Nets and Other Models of Concurrency (ToPNoC) II, 115-135 (2009)

50. Reijers, H.A., Liman Mansar, S.: Best practices in business process redesign: an overview and qualitative evaluation of successful redesign heuristics. Omega 33(4), 283-306 (2005)

51. Rinderle, S., Weber, B., Reichert, M., Wild, W.: Integrating process learning and process evolution - a semantics based approach. In: Proc. 3rd Int'l Conf. on Business Process Management (BPM'05), LNCS, vol. 3649, pp. 252-267. Springer (2005)

52. Simon, H.A.: The Sciences of the Artificial, 3rd edn. MIT Press (1996)

53. Smith, H., Fingar, P.: Process management maturity models (2004). http://www. bptrends.com

54. Speck, M., Schnetgöke, N.: Process Management: A Guide for The Design of Business Processes, chap. To-be Modeling and Process Optimization, pp. 135-163. Springer (2003)

55. The Object Management Group: Business process maturity model (BPMM) (2008). URL http://www.omg.org. http://www.omg.org

56. The Object Management Group: Business Process Model and Notation: Version 1.2 (2009). http://www.omg.org

57. Towers Watson: Executive compensation flash survey (2010). http://www.towerswatson.com

58. Vanderfeesten, I., Cardoso, J., Mendling, J., Reijers, H.A., van der Aalst, W.M.P.: Workflow Handbook 2007, chap. Quality metrics for business process models, pp. 179-190. Future Strategies (2007)

59. Vanderfeesten, I., Reijers, H.A., van der Aalst, W.M.: Evaluating workflow process designs using cohesion and coupling metrics. Computers in Industry 59(5), 420-437 (2008)

60. Weber, B., Reichert, M.: Refactoring process models in large process repositories. In: Proc. 20th CAiSE, LNCS, vol. 5074, pp. 124-139. Springer (2008)

61. Weber, B., Reichert, M., Mendling, J., Reijers, H.: Refactoring large process model repositories. Computers in Industry 62(5), 467-486 (2011)

62. Weber, B., Sadiq, S., Reichert, M.: Beyond rigidity - dynamic process lifecycle support: A survey on dynamic changes in process-aware information systems. Computer Science - Research and Development 23(2), 47-65 (2009)

63. Weske, M.: Business Process Management. Springer (2007)

64. Workflow Management Coalition: Terminology \& glossary 3.0 (1999). http://www. wfmc.org 